\title{
El problema indígena chileno en 1999.
}

\section{José Garrido Rojas.}

Desde comienzos de la década de los noventa, en particular desde 1992, sesquicentenerio de la llegada de los españoles a América, se aprecia el surgimiento de una serie de demandas por parte de grupos étnicos en el continente. En el caso de Chile, éstas abarcan desde la recuperación de tierras que les habrian sido usurpadas, al cuestionamiento del país ante tribunales internacionales $y$, en algunos casos, pretensiones de autonomía y/o autogobierno.

El tema étnico, como en otros lugares, ha aparecido unido a reivindicaciones medio ambientales, defensa del bosque nativo y de la biodiversidad.

La globalización del tema, es atribuida por el autor al surgimiento de un "etnonacionalismo indigenista" que interactía con el ecologismo en lo que denomina "la internacional ecólatra".

Asumiendo una amplia diferencia de interpretación del pasado por parte de antropólogos e historiadores, se hace una revisión de aspectos no siempre conocidos de este problema.

\section{Globalización del tema}

Desde hace meses, quizás años, se ha estado incubando y hecho presente, con fuerza notable y creciente violencia, una demanda mapuche; primero por tierras, supuestamente apropiada en forma ilegal por personas naturales y jurídicas en los últimos veinte años, no obstante que la prensa no informa de ninguna querella presentada en algún juzgado por esta causal. Luego, sobre formas de autogobierno todavía un tanto imprecisas. Y, violentas ataques a la institucionalidad chilena y al Gobierno en la Comisión de Derechos Humanos de la $\mathrm{ONU}$, donde se sugiere revertir la historìa hacia el siglo XVII. 
A fines de junio de 1999 hicieron presente su disconformidad con la situación imperante en sus respectivas regiones dirigentes Aymará y Rapanui y por la difícil situación en que se encuentran sus comunidades; nadie ignora la falta de recursos de la Municipalidad de Isla de Pascua, y no tiene por que ser diferente al resto del país rural, así como en las de Putre y General Lagos, en la provincia de Parinacota; Colchane y Pica en la provincia de Iquique; ello significa un grado importante de marginalidad en servicios de educación y salud que atienden al pueblo Aymará.

A la distancia se ha visto el caso Chiapas en Méjico, sin que se pensara que ello podría ocurrir en Chile. También hemos observado cómo el Gobierno de Canadá ha otorgado formas de autogobierno a minorías étnicas; también lo ha hecho Dinamarca con la minoría Inuit (llamada impropiamente Esquimales) en Groenlandia y el citado Canadá en $1900000 \mathrm{~km}^{2}$ constituyendo el Territorio Nunavut, donde habitan casi exclusivamente 27.000 inuit en torno al Artico. La diferencia con Chile que este es un Estado Unitario y Canadá es un país Federal; pero debe observarse que el primer paso es ridiculizar el estado unitario.

En Brasil el problema étnico se ha ligado al tema ecológico, a la diversidad biológica y el bosque nativo. Algo parecido ha ocurrido en Chile con, entre otros, el caso de los Pehuenches en Alto BioBio, que obstaculizan el desarrollo hidroeléctrico, para satisfacción de quienes dependen de la energía nuclear y de formas contaminantes de producción energética, castigadas por el mercado internacional; así se crean problemas a quien produce sin contaminar por la vía energética.

Se sabe, aunque sin mayor detalle, que Venezuela y otros países latinoamericanos también están sufriendo el problema. Además lo ha experimentado Australia y Nueva Zelandia, pero por ahora desconocemos los detalles. Es de esperar que los funcionarios diplomáticos acreditados por nuestra Cancillería en esos y otros países que tengan un problema parecido, habrán informado oportunamente al Presidente de la República; y el Ministerio de Relaciones Exteriores habrá armado el puzzle que, obviamente no es casual. A través de la Revista Diplomacia nos informamos que Colombia ha dispuesto que tres Senadores y diez Diputados sean elegidos directamente por etnias. (Revista Diplomacia, enero-marzo 1999).

Lo que no presenta dudas es que hay una Globalización del problema. Su base estaría en la aparición internacional de un "etnonacionalismo" apoyado 
por antropólogos; y éste etnonacionalismo indigenista interactúa con el ecologismo y lo que se podríamos denominar la "internacional ecólatra".

En el fondo hay un enfrentamiento entre los antropólogos que estiman que la llegada de los españoles en el siglo XVI dio comienzo a una "guerra interétnica" que todavía se mantiene y esta reavivándose; $y$, por el otro lado se encontrarían los historiadores que estiman que la llegada del español dio inicio a la formación de la raza chilena. "Explicado el fenómeno dentro de la historia de fronteras, se destaca el predominio de relaciones pacíficas, expresadas, principalmente, en el incremento del comercio, en el desarrollo del mestizaje, de la acción misionera y en la transformación de los métodos oficiales, todo lo cual contribuyó a un mayor acercamiento y contacto entre los habitantes del medio fronterizo". Ver Casanova y Villalobos. ${ }^{1 \text { y } 2}$ El enfoque del etnonacionalismo se puede encontrar en la interesante Revista LIWEN. ${ }^{3}$

Esta situación, obviamente, no es sólo en Chile. Lo mismo ha sido señalado en México en mayo de 1999, por intelectuales como Luis González de Alba (Del indigenismo) y Enrique Florescano (Etnia vs. nación) en la Revista Nexos. ${ }^{3 y 4}$

Por tanto se hace indispensable dar a conocer los antecedentes históricos fundamentales que permitan analizar la verdad. Se debe evitar a toda costa los síntomas de "complejo de culpa", que favoreció la reforma agraria; e hicieron populares medidas que se aplicarían a contar de 1966 hasta 1973, pero que se incubaron en los primeros años de la década de 1960.

La falta de antecedentes públicos y la demagogia puede hacer nuevamente que personas honestas se transformen en portavoces de demagogos y de quienes hacen un negocio de la "recaudación de fondos" de causas "nobles". Nunca faltan en los países desarrollados ricos dispuestos a aportar dinero. Es una nueva industria.

\footnotetext{
${ }^{1}$ Casanova Guardia, Holdenis. 1989. Las rebeliones araucanas del siglo XVIll. Ediciones de la Universidad de la Frontera. Serie Quinto Centenario. 111p Temuco. 1989.

2 Villailobos Sergio, Carlos Aldunate, Horacio Zapater, Luz María Méndez y Carlos Bascuñán. 198z. Relaciones fronterizas en la Araucanía. Ediciones de la Universidad Catölica de Chile, Santiago, 1982. Más antecedentes en Villalobos, Sergio. 1995. Vida Fronteriza en la Araucanía. El mito de la Guerra de Arauco. Editorial Andrës Bello. Noviembre de 1995. 215 p.

3 LIWEN. Anuario del Centro de Estudios y Documentación Mapuche Liwen. Temuko- Chile.

4 González de Alva, Luis. 1999. Del indigenismo. Revista Nexos. Mayo 1999. Www.nexos.com.mx
} 


\section{Orígenes}

En la segunda mitad del siglo pasado se celebran los denominados «Parlamentos» que dan término al proceso de «Pacificación de la Araucanía».

Aproximadamente 3000 familias indígenas, debidamente individualizadas, permitieron a la «Comisión Radicadora» cumplir con las disposiciones legales de ubicar y asignar a esas familias, tierras agrícolas en dominio exclusivo y perpetuo; Se otorgaron «Títulos de Merced» acompañados de los respectivos «Planos Topográficos», con indicación de sus deslindes, superficies y características, facilitando un rápido conocimiento de su ubicación y detectar a futuro posibles acciones de usurpación. ${ }^{5}$

La «Comisión radicadora contó con la colaboración de famosos topógrafos extranjeros como Schmidt, Bologna Ricci y otros, quienes confeccionaron los mapas de los títulos de dominio más modernos de la época e inscribirlos en un Registro especial, que se conserva hasta hoy día. Son los denominados «Títulos de Merced».

A fines de la década de 1960 y comienzos de la de 1970 se impone el ideal de priorizar sobre todo la preservación de instituciones culturales, llegando incluso a promover organizaciones estatales para aborígenes. ${ }^{6}$ Fue el caso del Instituto de Desarrollo Indígena (IDI).

El lento trabajo de titulación interna al que la legislación de la época propendía (Ley 14.511) se hace imposible con legislación de 1972 (Ley 17.729). ${ }^{7}$ La legislación protectora especial siempre estuvo definida por los derechos sobre las tierras de las reducciones.

\section{Problema del minifundio}

La continuada sobrepoblación en las reservas, la inestabilidad en el dominio de los herederos, inhibía toda inversión, provocando un agudo minifundio en la denominada "tierra indígenas" chilena. Un caso similar ha podido observarse en las "comunidades agrícolas" de la IV Región. A

5 Forescano, Enrique. 1999. Historia Patria. Etnia vs nación. Revista Nexos, Mayo 1999. www.nexos.com.mx

6 Hepp D., Ricardo. 1992. El chileno descendiente de etrias autóctonas. Mimeo. $7 \mathrm{p}$.

7 ODEPA. 1980. El chileno descendiente de grupos étnicos autóctonos. Mimeo. 8 p. 
este fenómeno se le denomina minifundio encubierto

Debe recordarse, que en lo que a "propiedad indígena" se refiere no sólo existía una legislación especial, sino también "Jueces de Indios" para tratar los casos civiles.

El problema del minifundio ha sido un mal endémico del sector rural chileno. A los minifundios de las Comunidades de Coquimbo de la "Propiedad o tierra indígena" que han sido los cuadros más tradicionales, debiera agregarse los de Maule, Chiloé y gran parte de la zona de la costa del país. Estos minifundios encubiertos derivan de problemas de herencia no resueltos, por la falta de títulos de propiedad, y se trata de comunidades de hecho, por lo que no hay deslindes; y no se han observado su gravedad y profundidad a simple vista, incluso estudiándose por fotografía aérea.

El problema de títulos en los minifundios, dejaba a los tenedores de la tierra al margen del crédito agrícola. La situación era más grave en la población indígena, ya que el organismo creado para su atención -Instituto de Desarrollo Indígena (IDI) - casi nunca contó con los recursos suficientes para sus programas de asistencia técnica, crédito, educación, etc. Por tanto, las "reservas" quedaron excluidas de las medidas generales a favor del minifundio.

Como el título original (merced) los hacia aparecer como comuneros, con derechos iguales, tratando de protegerlos hacia fuera, producía otras consecuencias; tales como que a ninguno se le reconocían legalmente sus posesiones individuales y propiedad particular, no se introdujeron mejoras y la inversión fue nula. Nadie pudo testar en forma obligatoria para sus herederos y ningún heredero pudo disponer de su parte (salvo arreglos amigables).

\section{Estudio del minifundio}

En 1976 desde la Vicepresidencia de INDAP y Dirección del Instituto de Desarrollo Indígena, el Ingeniero Agrónomo Ricardo Hepp Dubiau ${ }^{8}$, contrata un Estudio del Minifundio en Chile a la empresa consultora PROPLAN. De esta manera de buscó determinar la localización espacial del minifundio chileno. Y, obviamente, se pudo localizar detalladamente también el minifundio indígena. Más detalladamente se estudió el caso de la comuna de Perquenco en donde, además de analizar su trágica situación, se propuso un Plan de Desarrollo Rural. ${ }^{9}$ 
La situación legal fue enfrentada por una Comisión designada por el Ministro de Agricultura Alfonso Márquez de la Plata ver 6 que propuso el Decreto Ley 2 568, de 28 de marzo de 1979, que facilitó el acceso a la tierra a los miembros de las comunidades que lo solicitaran. ${ }^{10}$

El Instituto de Desarrollo Agropecuario (INDAP) veló a través del Archivo General de Asuntos Indígenas, por el resguardo de los títulos de merced, manteniendo en forma actualizada el registro Conservador de la Propiedad Indígena." Desde el Gobierno del Presidente Aylwin to hace CONADI dependiente del Ministerio de Planificación (MIDEPLAN).

El programa contempla la asistencia judicial y extrajudicial a los ocupantes de las reservas indígenas, en lo relativo al ejercicio y mantención de sus derechos, incluyendo la realización de peritajes y levantamientos topográficos.

Fruto de la legislación vigente hacia 1978 se habían dado título sólo a unas 800 mercedes de las 3000 originales

El Decreto Ley 3.256 de 1980, sobre exenciones tributarias, contiene también una norma importante relacionada con el sector mapuche. Este dispone que las hijuelas resultantes de la división de las comunidades quedarán exentas -por un plazo de 20 años- de la contribución de Bienes Raíces y suspende el cobro de este impuesto en aquellas comunidades que se encuentran actualmente en proceso de división.

\footnotetext{
- Ley 17729 del 26 septiembre de 1972. Define a los indigenas y los somete a un ordenamiento especial; coloca sus propiedades en un régimen de excepciôn, al igual que sus herencias y estado civil. Crea el Instituto de Desarrollo Indígena (IDI) fundiendo labores como las de tribunal administrativo, otorgamiento de créditos, construcción de postas y escuelas, etc.

- Ricardo Hepp Dubiau Ing. Agr. , Profesor Titular de la U de Chile, ex Director de la Escuela, Facultad de Agronomia, U de Chile. Vicepresidente de INDAP entre 1976-1982.

'valenzuela Vial, Joaquín y losé Garrido Rojas.1982. "El proyecto Perquenco. Un caso de subdesarrollo." Revista del ingeniero Agrónomo. № 26, pág. 24-30. Agosto. 1982.

"Alfonso Márquez de la Plata, Ing. Agr., Ministro de Agricultura entre abril de 1978 y diciembre de 1980. La comisiôn estuvo integrada por Ricardo Hepp, Cristōbal Unterrichter, experto FAO, Alberto Daiber, abogado y Juez de Indios de la Unión, contando con la asesoría de don Julio Phillipi lzquierdo.
} 


\section{Programa de Regularización de la Propiedad Indígena}

\section{Reservas y superficies de Títulos de Merced}

$\begin{array}{lll}\text { Región } & \mathbf{N}^{\text {o }} \text { de Reservas } & \text { Superficie en hectáreas } \\ \text { VIII } & 83 & 26.363,59 \\ \text { IX } & 2.317 & 407.799,06 \\ X & 518 & 76.601,13 \\ \text { Total } & 2.918 & 510.767,78\end{array}$

Fuente: INDAP. Cuadro IV.18. ${ }^{12}$

Número de Títulos obtenidos de reservas Indígenas y Superficie de Reservas y Predios saneados (hectáreas) 1979-1988

Regiones Año 1979-1988

$\begin{array}{lll}\text { Región } & \text { Total Títulos } & \text { Total has. San. } \\ \text { VIII } & 2.058 & 43.456,29 \\ \text { IX } & 63.429 & 374.196,33 \\ \text { X } & 7.957 & 101.904,94 \\ \text { Total } & 73.444 & 519.257,56\end{array}$

Fuente: INDAP Cuadros IV.21 y IV. 22.'2

12 Decreto Ley № 2.568 (28 de marzo de 1979) modificado por el D.L. № 2.570 del mismo año. Abordỏ el problema histórico de las llamadas "Reservas Indigenas", que en gran parte permanecian aûn indivisa, constituyendo un problema de minifundio encubierto, agravado por la carencia de títulos de propiedad que los margina del crédito. Este decreto dispuso que las Comunidades Mapuches podrían solicitar a INDAP la tramitación correspondiente, para obtener sus títulos de dominio. Los gastos que demanden la división de éstas comunidades serän absorbidos por el Estado. Esta acción es apoyada, además, con la entrega de crédito y asistencia técnica que apuntan al desarrollo tecnológico de los predios, así como al beneficio global del grupo familiar. 


\section{Creación de archivo en microfichas}

Desde 1978 se inició la entrega de tierras individuales a los miembros de las reservas que lo solicitaran. Pero al poco andar, enemigos del proceso colocaron bombas en el edificio del IDI en Temuco y trataron de quemar el archivo.

Ante esa situación la Facultad de Agronomía de la Universidad de Chile sugirió a las autoridades microfilmar el archivo. Así se origina el Archivo de Microfichas. ${ }^{13}$

\section{Sugerencias de utilización de la información disponible}

Frente a los acontecimientos que se desarrollan en el país en el año 1999, con una evidente participación internacional se sugiere informar a la opinión pública del contenido del Archivo Indígena.

Está en elaboración un Programa para la utilización y Análisis Histórico del Archivo desde diversos ángulos, para lo cual se puede estudiar la evolución de Propiedad Indígena desde la creación del Archivo.

\section{Situación en 1999}

El problema del minifundio y la marginalidad de la familia rural y la agricultura mapuche se ha visto complicado por el enfoque indigenista ecólatra de fines de siglo. No desean que se trate como problema agrícola del minifundio chileno, sino con características especiales por tratarse de una etnia ligada a un ecosistema particular. Ligan la singularidad a la ecología en boga. Sostiene Bengoa ${ }^{14}$ : "Los mapuches tienen una relación vital por ejemplo no sólo con una tierra en particular donde han nacido y' crecido, sino con el sur de Chile, con sus lluvias y' su paisaje."(pág. 13)

\footnotetext{
${ }^{13}$ Chile. Ministerio de Agricultura. Divisiōn de estudios y Presupuesto. 1989. Programa Regularización Propiedad indigena. Pág. 230. En: La agricultura chilena durante el gobierno de las Fuerzas Armadas y de Orden. 14 Calandra Bustos, Pedro. 1999. Archivo Indígena. Informe № 1 Elaborado por acuerdo del Grupo de Trabajo del Archivo Indígena con el señor Rector de la Universidad de Chile.
} 
Para justificar el autogobierno que sugiere, distingue entre tierra y territorio, corrigiendo a la Real Academia Española, que es muy clara en sus acepciones 6, 7 y 9. Sostiene Bengoa: "El caso de la distinción entre "tierras" y "territorio" es significativo. El primero se refiere al derecho individual de cualquier persona humana de contar con una propiedad donde poder desarrollar su vida y reproducir sus medios de existencia. Es el derecho a gozar de la propiedad privada de la tierra o de otras formas de propiedad. Territorio en cambio se refiere a un concepto más abstracto (motherland, dicen los ingleses) y es el conjunto físico, pero sobre todo simbólico en el que habita un pueblo. Es un concepto mucho más ligado con la ecología y la cultura y determina muchas veces las formas de vida." ( pág. 12 y 13).

El otros aspecto que se sugiere con particular énfasis es que Chile ratifique el Convenio 169 sobre pueblos indígenas y tribales, 1989, el que hasta de agosto de 1999 lo ha sido sólo por 13 países. ${ }^{15}$ y 16

Durante el período ordinario de sesiones del Congreso en 1999, un grupo de parlamentarios presentó un proyecto de reforma constitucional por el cual los Mapuches tendrían derecho a designar 3 senadores y 10 diputados al Congreso Nacional; CONADI se transformaría en un Parlamento Indígena para los Asuntos Autonómicos. Como ya hemos señalado, reacciones Aymará y Rapanui no se han dejado esperar y sus representantes han manifestado que ellos también están abandonados, lo cual es bastante cierto.

Los proponentes de este enfoque han entrado en un tema que puede poner en situación delicada la organización fundamental de la República; que se podría solicitar un región Aymará autónoma que incluya parte de Bolivia, Argentina y Chile, ya que es una etnia supranacional como los kurdos; $y$, que esto puede ser el inicio de un apartheid que se sabe donde se inicia pero no donde termina.

15 Bengoa, José. 1999. Los derechos de las minorías y los pueblos indígenas: debate internacional. Revista Diplomacia. Pág. 7-21. Enero-marzo 1999.

${ }^{16}$ Bengoa, Josê. 1997. Los derechos de los pueblos indigenas. El debate acerca de la declaración internacional. En Liwen № 4, junio 1997. Temuco: centro de Estudios y Documentación Mapuche Liwen, pp.193*215. 